\title{
EFFECT OF WHOLE AMARANTH FLOUR ON BREAD PROPERTIES AND NUTRITIVE VALUE
}

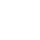

J.M. Sanz-Penella ${ }^{\mathrm{a}, \mathrm{b}}$, M. Wronkowska ${ }^{\mathrm{b}}$, M. Soral-Smietana ${ }^{\mathrm{b}}$, M. Haros ${ }^{\mathrm{a}}{ }^{\text {* }}$

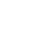

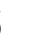

${ }^{\mathrm{b}}$ Institute of Animal Reproduction of Food Research of the Polish Academy of Sciences, Division of Food Science, Department of Functional Properties of Food, 10 Tuwima

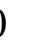
Str., 10-747 Olsztyn, Poland.

\footnotetext{
*Corresponding Author. Tel.: +34 9639000 22; Fax.: +34 963636301
}

e-mail: mharos@iata.csic.es (Monika Haros) 


\section{$1 \quad$ Abstract}

2 This study investigated the effect of replacing wheat flour by whole Amaranthus 3 cruentus flour (up to $40 \mathrm{~g} / 100 \mathrm{~g}$ ) to evaluate its potential utility as a nutritious

4 breadmaking ingredient. The incorporation of amaranth flour significantly increased 5 protein, lipid, ash, dietary fibre and mineral contents. Breads with amaranth have 6 significantly higher amounts of phytates and lower myo-inositol phosphates, which 7 could predict low mineral bioavailability at high levels of substitution (30-40 g/100g).

8 An increase in crumb hardness and elasticity was observed, and tristimulus colour

9 values were significantly affected when the amaranth concentration was raised. Mineral 10 contents, both micro- and macroelements, were increased significantly by the wheat 11 flour substitution. Whole amaranth flour could be used as a partial replacement for 12 wheat flour in bread formulations, increasing the product's nutritional value and raising 13 dietary fibre, mineral and protein levels, with a significant slight depreciation in bread 14 quality when used in proportions between 10 and $20 \mathrm{~g} / 100 \mathrm{~g}$. Thus, the inclusion of 15 amaranth flour could be limited to a maximum proportion of $20 \mathrm{~g} / 100 \mathrm{~g}$, thereby 16 maintaining both product quality as well as the nutritional benefit of this ingredient.

24 Key words: whole amaranth flour, bread, minerals, phytate, bread performance. 


\section{1}

2 Whole grain may increase the nutritional value of bakery products made with refined

3 wheat flour (Marquart, Asp \& Richardson, 2004; Sanz-Penella, Collar \& Haros, 2008;

4 Miller Jones, 2009). One possibility would be to include whole amaranth grain in bread

5 formulations or bakery products. Amaranth is one of the most important pre-Hispanic

6 crops and was part of the diet of the Aztecs, Mayas, Incas and other pre-Colombian

7 civilizations. It belongs to the family of pseudocereals as it has similar properties to

8 those of cereals but botanically does not belong to that family. The genus Amaranthus

9 includes more than 60 species that are grown in various parts of the world, such as

10 Central and South America, India, Africa and China (Budin, Breene, \& Putnam, 1996).

11 There is increasing interest in the consumption of this genus in Europe, the USA and

12 Japan, and it is already grown in some parts of these regions. Most species are

13 considered as opportunistic weeds and only three of them, A. caudatus, A. cruentus and

14 A. hypochondriacus, are commonly consumed by humans as a seed or used as a

15 functional ingredient in foods (Gamel, Linssen, Mesallam, Damir, \& Shekib, 2006). The

16 amaranth grain can be toasted, popped, extruded or milled into flour and can therefore

17 be consumed as such or included in other cereal products such as bread, cakes, muffins,

18 pancakes, cookies, dumplings, crepes, noodles and crackers. The nutritional quality of

19 amaranth seed is higher than that of most cereal grains, owing to its high protein content

20 and balanced essential amino acid composition (Oszvald, Tamás, Rakszegi, Tömösközi,

21 Békés \& Tamás, 2009). Moreover, amaranth grain protein is rich in lysine, which is

22 usually deficient in cereal grains. The total mineral content has been reported to be generally higher than that observed in cereal grains, especially calcium and magnesium

24 (Alvarez-Jubete, Auty, Arendt, \& Gallagher, 2010). On the other hand, it is

25 characterized by higher dietary fibre and lipid content than most cereals and also

26 contains between 50 and $60 \mathrm{~g}$ of starch per $100 \mathrm{~g}$ of grains (Alvarez-Jubete et al., 2010). 
1 Amaranth oil is reported to have high levels of tocotrienols and squalene, which are

2 natural organic compounds that are involved in the metabolism of cholesterol and that

3 could play an important role in lowering LDL-cholesterol in blood (Bodroza-Solarov,

4 Filiocev, Kevresan, Mandic \& Simurina, 2008; Budin et al., 1996). The optimal

5 nutritive composition of this seed has made its use attractive as a blending food source

6 to improve the nutritional value of some cereal by-products. Protein content was

7 significantly increased by up to $4.4 \mathrm{~g} / 100 \mathrm{~g}$ by using popped amaranth grain or amaranth

8 flour in bread, with maximum levels of substitution of $20 \mathrm{~g} / 100 \mathrm{~g}$ (Bodroza-Solarov et

9 al., 2008; Tosi, Re, Masciarelli, Sanchez, Osella, \& de la Torre, 2002). Mineral and

10 dietary fibre contents in bread and pasta were also significantly increased by flour

11 substitution at levels up to $20 \mathrm{~g} / 100 \mathrm{~g}$ (Dyner et al., 2007). With regard to sensory

12 appreciation, bakery products incorporating amaranth have been accepted at levels up to

13 15-25 g/100g (Bodroza-Solarov et al., 2008; Sindhuja, Sudha, \& Rahim, 2005). Despite

14 all the virtues attributed to amaranth grain, there have been reports of the presence of

15 some anti-nutritional factors, such as phenolic compounds, trypsin inhibitors and phytic

16 acid (myo-inositol hexakisphosphate, Ins $P_{6}$ ) or its salts, the phytates (Gamel et al.,

17 2006). Phenols and trypsin inhibitors are at such low levels that they do not present a

18 risk to the nutritional status (Bodroza-Solarov et al., 2008). Phytate content in various

19 whole grains of the Amaranthus genus has been published, ranging from 4.8 to 9.4

$20 \mu \mathrm{mol} / \mathrm{g}$ (Lorenz \& Wright, 1984; Teutonico \& Knorr, 1985; Colmenares de Ruiz \&

21 Bressani, 1990). Phytic acid intake has been reported to have favourable effects, such as

22 antioxidant function, prevention of heart diseases and anticarcinogen effect, which it

23 performs through its hydrolysis products (Haros, Carlsson, Almgrem, Larsson

24 Alminger, Sandberg, \& Andlid, 2009; Kumar, Sinha, Makkar \& Becker, 2010). Phytic

25 acid is strongly negatively charged and thus has a great potential for complexing

26 positively charged multivalent cations such as calcium, magnesium, zinc, copper and 
1 iron. This has adverse effects on mineral bioavailability, owing to the formation at

2 physiological $\mathrm{pH}$ values of insoluble complexes which are non-absorbable in the human

3 gastrointestinal tract (Sandberg, Hulthen \& Türk, 1996; Lopez, Krespine, Guy,

4 Messager, Demigne \& Remesy, 2001). The negative health effects of phytates are more

5 significant in developing countries and in risk populations owing to their higher

6 incidence of undergoing mineral deficiencies (Hurrell, Reddy, Juillerat \& Cook, 2003).

7 During the breadmaking process phytate is sequentially hydrolysed by the action of the

8 cereal's own phytate-degrading enzymes. However, wholegrain breads still contain high

9 phytate levels owing to a slow and inefficient enzymatic dephosphorylation (Türk \&

10 Sandberg, 1992; Haros, Rosell \& Benedito, 2001). Some strategies to reduce or

11 eliminate phytate in breadmaking processes include increasing fermentation time,

12 lowering process $\mathrm{pH}$ by the inclusion of sourdough, or adding exogenous phytase (Türk

13 et al., 1992; Lopez et al., 2001; Sanz-Penella et al., 2008; Sanz-Penella, Tamayo-

14 Ramos, Sanz \& Haros, 2009; Sanz-Penella, Tamayo-Ramos, Wronkowska, Soral-

15 Smietana, \& Haros, 2010).

16 Much of the published research on phytate content in baking products has focused on

17 wholegrain breads made from wheat, rye, rice or mixtures of them, but no data are

18 available for the amount of phytate in bread made with amaranth flour and there is a

19 lack of scientific reports regarding this field. Therefore the purpose of the present work

20 was to provide further information on how replacing wheat flour by whole amaranth

21 flour from Amaranthus cruentus (up to $40 \mathrm{~g} / 100 \mathrm{~g}$ ) affects the phytate content of bread

22 and its performance, and to evaluate its potential utility as a nutritious breadmaking 23 ingredient.

\section{Materials and methods}




\section{$1 \quad$ 2.1. Materials}

2 The commercial grain amaranth and flour were purchased from the local Spanish

3 market. Amaranthus cruentus was used in this research, whose colour was yellow-gold.

4 The characteristics of the commercial wheat and amaranth flours used were $(\mathrm{g} / 100 \mathrm{~g})$ :

5 moisture $15.28 \pm 0.01$ and $11.04 \pm 0.01$; protein $(\mathrm{Nx} 5.70) 11.70 \pm 0.06$ and $(\mathrm{Nx} 5.85)$

$6 \quad 14.04 \pm 0.01$ dry matter (d.m.); fat content $1.11 \pm 0.01$ and $6.04 \pm 0.01$ d.m.; and ash

$7 \quad 0.53 \pm 0.01$ and $2.44 \pm 0.08$ d.m., respectively. Mineral content and the amount of myo-

8 inositol phosphates are summarized in Table 1. Compressed yeast (Saccharomyces

9 cerevisiae, Lesaffre, Wołczyn, Poland) was used as starter.

\section{2.2. Breadmaking procedure}

12 The bread dough formula consisted of commercial wheat flour (500 g) with replacement

13 by different concentrations of amaranth flour, 0, 10, 20, 30 and $40 \mathrm{~g} / 100 \mathrm{~g}$ (Control, 10WAF, 20WAF, 30WAF and 40WAF, respectively), compressed yeast (15 g), sodium salt (5 g) and tap water up to optimum absorption (500 Brabender Units), between 51.0 and $58.4 \mathrm{~g}$ of water/100g of flour, conditioned by the formula. The ingredients were mixed (Kitchen Aid, Long Beach, USA) for 4.5 to $5.5 \mathrm{~min}$, depending on the formulation, and the doughs were fermented (ZBPP, Bydgoszcz, Poland) for $60 \mathrm{~min}$ at

$1930{ }^{\circ} \mathrm{C}$ and $65 \%$ relative humidity. The doughs were then kneaded, divided into three 20 pieces of $250 \mathrm{~g}$, put into pans and proofed under the above-mentioned conditions for 60 21 min. After the fermentation step, the doughs were baked in an electric oven with an 22 incorporated proofing chamber (ZBPP, Bydgoszcz, Poland) at $225{ }^{\circ} \mathrm{C}$ for $20 \mathrm{~min}$. 23 Finally, the bread loaves were cooled at room temperature for $60 \mathrm{~min}$ for their subsequent analysis. The experiments were done in triplicate. 
2 Starch content was measured by the total starch assay procedure (AOAC, 1996). The

3 resistant starch, considered as the starch fraction not hydrolysed in vitro by pancreatic

$4 \quad \alpha$-amylase, EC 3.2.1.1, from porcine pancreas (Sigma, A-3176, St. Louis, USA), was

5 determined in dried bread crumb according to the Champ, Martin, Noah \& Gratas

6 method (1999). The products of hydrolysis were extracted with $80 \mathrm{~g} / 100 \mathrm{~g}(\mathrm{v} / \mathrm{v})$ ethanol

7 and the non-digested material was solubilised in $2 \mathrm{~mol} / \mathrm{L} \mathrm{KOH}$, and then hydrolysed

8 with amyloglucosidase EC 3.2.1.3 (Novozymes, AMG 300L, Bagsvaerd, Denmark) into

9 glucose. The free glucose was finally quantified with a glucose oxidase/peroxidase

10 analysis kit (Liquick Cor-Glucose 120, Cormay, Lublin, Poland) and measured

11 spectrophotometrically at $500 \mathrm{~nm}$. Protein determination was carried out by the

12 Kjeldahl technique. Lipid content was extracted with ethylic ether under reflux

13 conditions in a Soxhlet. Ash content was determined in a furnace by incineration at 910

$14{ }^{\circ} \mathrm{C}$. The dietary fibre content was measured by the total dietary fibre assay procedure

15 (AOAC, 1991). Mineral contents were quantified using the atomic absorption

16 spectroscopy method with a Unicam 939 spectrometer (Labexchange, Burladingen,

17 Germany) equipped with ADAX data base, background correction and cathode lamps

18 (Wronkowska, Troszynska, Soral-Smietana \& Wolejszo, 2008). All samples were wet

19 mineralized with a mixture of acids: nitric and perchloric (3:1). Potassium was assayed

20 with the photometric flame method and phosphorus was investigated with the

21 colorimetric method by molybdate with hydroquinonate and sodium sulphate (IV). For

22 the validation of calcium measurement, a solution of lanthanum chloride was added to

23 all samples in amounts ensuring a $0.5 \mathrm{~g}$ of $\mathrm{La}^{3+} / \mathrm{ml}$ (Whiteside \& Miner, 1984). The

24 residual concentration of $\operatorname{Ins} P_{6}$ in the bread and the lower myo-inositol phosphates

25 generated were measured following the high pressure liquid chromatographic method

26 described by Türk et al. (1992), later modified by Sanz-Penella et al. (2008). 


\section{$2 \quad$ 2.4. Technological parameters}

3 Technological parameters analysed were: moisture content $(\mathrm{g} / 100 \mathrm{~g})$ of whole bread,

4 loaf specific volume $\left(\mathrm{cm}^{3} / \mathrm{g}\right)$ and crumb texture using an Instron 1011 compression

5 device (Instron Ltd., High Wycombe, England). The crumb samples of fresh bread (2.0

$6 \times 2.0 \times 2.0 \mathrm{~cm}$ ) were twice compressed to $70 \%$ strain at a crosshead speed of 20

$7 \mathrm{~mm} / \mathrm{min}$ (Sadowska, Błaszczak, Fornal, Vidal-Valverde \& Frias, 2003). Hardness

8 expressed as maximum force during first compression, $\mathrm{F}_{1}\left(\mathrm{kPa}, \mathrm{Pa}=\mathrm{N} / \mathrm{m}^{2}\right)$, elasticity

9 and cohesiveness expressed as ratios of maximum forces, $F_{2} / F_{1}$, and energies, $E_{2} / E_{1}$,

10 determined in both compressions, and gumminess, characterized by the expression $\mathrm{E}_{2} \mathrm{X}$

$11 \mathrm{~F}_{1} / \mathrm{E}_{1}(\mathrm{kPa})$. Additionally, crumb springiness was described by volume recovery

12 coefficient (VRC), expressed as the ratio of sample volumes before second and first

13 compression, $\mathrm{V}_{1} / \mathrm{V}_{2}$, according to Sadowska et al. (2003). At least eight replicates were

14 made; two loaves per baking were used in the analysis. Digital image analysis was used

15 to measure bread crumb structure. Images were previously squared at 80 pixels per $\mathrm{cm}$

16 with a flatbed scanner (Epson Perfection V200 Photo, Nagano, Japan) supported by

17 Epson Creativity Suite Software. Two $20 \mathrm{~mm}$ x $20 \mathrm{~mm}$ square fields of view of the

18 central slice (20 mm thick) of each of two loaves were used, thereby yielding four

19 digital images per each baking. Data was processed using Sigma Scan Pro Image

20 Analysis Software (version 5.0.0, SPSS Inc., San Jose, USA). The crumb features

21 chosen were cell area/total area $\left(\mathrm{cm}^{2} / \mathrm{cm}^{2}\right)$, wall area/total area $\left(\mathrm{cm}^{2} / \mathrm{cm}^{2}\right)$, number of

22 cells per $\mathrm{cm}^{2}$ and mean cell area $\left(\mathrm{mm}^{2}\right)$ (Sanz-Penella et al., 2009, 2010). The

23 instrumental measurement of the bread crust and crumb colour was carried out with a

24 HunterLab ColorFlex (Reston, USA), and the results were expressed in accordance with

25 the CIELab system with reference to illuminant D65 and a visual angle of $10^{\circ}$. The

26 measurements were performed through a $3 \mathrm{~cm}$ diameter diaphragm containing an 
1 optical glass. The parameters determined were $\mathrm{L}^{*}\left(\right.$ Lightness, $\mathrm{L}^{*}=0$ [black] and $\mathrm{L}^{*}=$

2100 [white]), $\mathrm{a}^{*}$ and $\mathrm{b}^{*}$ (colour-opponent dimensions, $\left[-\mathrm{a}^{*}=\right.$ greenness and $+\mathrm{a}^{*}=$

3 redness], $\left[-b^{*}=\right.$ blueness and $+b^{*}=$ yellowness $]$ ). Five replicates were made (one loaf

4 per baking was used in the analysis, so 15 replications were made in all). Each bread

5 was cut in two halves to measure the crumb colour. All the measurements were made by

6 placing the sample directly on the colorimeter diaphragm.

7

8 2.5. Statistical analysis

9 Results were expressed as the mean values of at least 3 replications. Multiple sample

10 comparison of the means and Fisher's least significant differences (LSD) were applied

11 to establish statistical significant differences between treatments. All statistical analyses

12 were carried out with the Statgraphics Plus 7.1 software (Bitstream, Cambridge, MN)

13 and differences were considered significant at $p<0.05$.

15 3. Results and discussion

16 3.1. Bread composition

17 The chemical composition of the breads supplemented with different percentages of 18 whole amaranth flour is presented in Table 2. The incorporation of amaranth flour to the 19 formulation, whatever percentage was incorporated, gradually and significantly 20 increased proteins, lipids and ash content and decreased the starch content with regard 21 to the control sample. The greater levels of proteins, lipids and ash registered in the raw 22 amaranth flour with regard to the wheat flour directly affected the increase of these 23 parameters, as expected. These results are in agreement with other studies on breads 24 incorporating different types of amaranth (Diner et al., 2007; Bodroza-Solarov et al., 25 2008). The same tendency was observed for the loaf moisture content and total dietary 26 fibre, modifying significantly from 38.79 to $41.94 \mathrm{~g} / 100 \mathrm{~g}$ and from 3.79 to $5.90 \mathrm{~g} / 100 \mathrm{~g}$, 
1 respectively, with the replacement of wheat flour by amaranth flour. The moisture

2 increase was fundamentally due to the inclusion of a greater amount of insoluble dietary

3 fibre with the amaranth flour, whereas the soluble fibre remained almost constant

4 without significant changes. The resistant starch content registered slight modifications

5 among samples, being higher in samples with the pseudocereal. The mineral content

6 increased significantly as a result of the replacement of wheat flour as was expected,

7 owing to the flour composition (Table 1). The substitution of $40 \mathrm{~g} / 100 \mathrm{~g}$ increased the

8 amount of $\mathrm{Cu}$ from 2.25 to $4.21 \mu \mathrm{g} / \mathrm{g}$, Mn from 6.39 to $19.41 \mu \mathrm{g} / \mathrm{g}$, $\mathrm{Zn}$ from 11.65 to

$924.91 \mu \mathrm{g} / \mathrm{g}$, Fe from 18.85 to $43.74 \mu \mathrm{g} / \mathrm{g}$, Ca from 0.31 to $0.99 \mathrm{mg} / \mathrm{g}, \mathrm{Mg}$ from 0.29 to

$10 \quad 1.32 \mathrm{mg} / \mathrm{g}$ and $\mathrm{K}$ from 1.88 to $3.21 \mathrm{mg} / \mathrm{g}$, respectively. However, the Na level decreased

11 or remained unchanged by the substitution because it was included in the formulation as

12 an ingredient (3.72-4.08 $\mathrm{mg} / \mathrm{g})$. In general, white bread has a low mineral content and

13 should be supplemented to meet the daily requirements for different elements (Dyner et

14 al., 2007; Skrbic \& Filipcev, 2008). In this context, whole grain breads are known to be

15 richer sources of macro- and microelements than breads made of refined flours. The

16 amounts of $\mathrm{Cu}, \mathrm{Zn}, \mathrm{Fe}$ and $\mathrm{Mg}$ in whole wheat bread are similar to the content in bread

17 with 30-40 g/100g amaranth flour, while the amounts of Mn, Ca and K are close to half

18 (Skrbic et al., 2008). Table 3 shows the contributions of mineral intake from bread with

19 or without amaranth to the dietary reference intakes (DRIs) given by the Food and

20 Nutrition Board of the Institute of Medicine, National Academy of Science (NAS,

21 2004), taking into account the World Health Organization's recommendation of a daily

22 intake of $250 \mathrm{~g}$ of bread per person. When expressed in terms of DRIs, the control bread

23 contributes $38.3 \%$ of the $\mathrm{Cu}$ recommended for adults, whereas the breads incorporating

24 amaranth contribute significantly increased intakes of this mineral, ranging from 43.0 to

$2569.6 \%$ (10WAF and 40WAF, respectively). Moreover, consumption of the control

26 bread satisfies 42.5 or $54.3 \%$ of the Mn recommendation, whereas bread with 20-30 
$1 \mathrm{~g} / 100 \mathrm{~g}$ amaranth flour could cover the requirements of this microelement in adults

2 (Table 3). Regarding Zn, consumption of the control bread would provide only a fifth

3 (or less) of the daily requirement in adults, while the bread made with amaranth flour

4 could provide nearly $50 \%$ of these daily requirements in females. The same tendency

5 was observed with $\mathrm{Fe}$, where $20 \%$ flour substitution could supply more than $50 \%$ of the

6 daily requirement of this mineral in males. The macronutrients followed the same trend.

7 About $50 \%$ of the requirements of $\mathrm{Mg}$ and $\mathrm{P}$ could be covered by the inclusion of

8 amaranth in the bread formulation (30-40 g/100g). However, the $\mathrm{P}$ in cereal and

9 pseudocereal whole flours corresponds almost exclusively to phytic phosphorus; it

10 might not be bioavailable unless it is hydrolysed during the fermentation by the action

11 of the endogenous phytase in the cereal. Moreover, it is known that the bioavailability

12 of minerals depends on the presence of certain anti-nutrients, including phytic acid,

13 which act as inhibitors of mineral uptake and have adverse effects on their

14 bioavailability, owing to the formation of insoluble complexes (Sandstrom \& Sandberg,

15 1992; Lopez et al., 2001). Solubility in the gastrointestinal media (bioaccessibility) is a

16 pre-requisite for absorption by enterocytes in the intestine. In this context, it is assumed

17 that the predicted intakes that are derived from DRIs for the minerals analysed in this

18 study are almost certainly overestimated. It is therefore necessary to find out the content

19 of this anti-nutritional compound in the bread samples. In order to determine how the

20 inclusion of amaranth flour affected phytate and lower myo-inositol phosphate

21 concentrations, the amount of $\operatorname{Ins} P_{6}$ and its hydrolysis products were measured (Table

22 2). The amount of phytates in the amaranth seed was $21.1 \mu \mathrm{mol} / \mathrm{g}$ in dry matter

23 (Table1), which was higher than in previous investigations. The phytate content

24 reported in amaranth from A. cruentus, A. hypochondriacus and A. hybridus showed a

25 wide variation between 4.8 and $9.4 \mu \mathrm{mol} / \mathrm{g}$ (Lorenz et al., 1984; Teutonico et al., 1985;

26 Colmenares de Ruiz et al., 1990), taking into account the fact that the Ins $P_{6}$ content in 
1 grain depends on many factors (Bohn, Meyer \& Rasmussen, 2008). The inclusion of

2 whole amaranth flour in the bread formulation significantly increased the amount of

3 phytate from non-detectable values to $2.35 \mu \mathrm{mol} / \mathrm{g}$ (d.m.) for the control sample and 40

$4 \mathrm{~g} / 100 \mathrm{~g} \mathrm{WAF}$, respectively. The same tendency was observed in Ins $P_{5}$, and even more in

$5 \quad \operatorname{Ins} P_{4}$ and $\operatorname{Ins} P_{3}$, which increased significantly with the inclusion of amaranth flour.

6 Phytates are mainly present in outer layers of the grain, and during the breadmaking

7 process endogenous phytate-degrading enzymes with the potential to hydrolyse phytates

8 to Ins $P_{5}-$ Ins $P_{3}$ could be active (Sanz-Penella et al., 2008; 2009). The fermentation stage

9 used in the breadmaking process in this study was maintained for two hours.

10 Consequently, the endogenous phytase could have had enough time to significantly

11 reduce the phytate content present in the amaranth flour. Even so, the amount of Ins $P_{6}$

12 and lower myo-inositol phosphates increased as the whole amaranth flour was

13 introduced in the formulation. The phytate/minerals molar ratios are used to predict the

14 inhibitory effect of $\operatorname{Ins} P_{6}$ on the bioavailability of minerals (Ma, Jin, Plao, Kok, Guusie

15 \& Jacobsen, 2005). The phytate/calcium molar ratio could impair calcium

16 bioavailability in humans at values higher than 0.24 . In the case of iron, if the molar

17 ratio is more than 1 ; whereas if the phytate/Zn molar ratio is higher than 5 the

18 bioavailability of $\mathrm{Zn}$ could be less than $50 \%$ (Ma et al., 2005). The sample made with

$1940 \mathrm{~g} / 100 \mathrm{~g}$ whole amaranth flour had a phytate/Zn molar ratio value higher than 5

20 (phytate/Zn: 6.17). This sample and 30WAF both showed phytate/Ca molar ratio values

21 higher than 0.24 (0.95 and 0.43 , respectively). The phytate/Fe molar ratio showed

22 values higher than 1 for the 30WAF (1.42) and 40WAF (3.00) samples. The high

23 phytate concentration resulting from the inclusion of a high proportion of whole

24 amaranth flour in the bread formula $(30-40 \mathrm{~g} / 100 \mathrm{~g})$ could lead to a mineral

25 bioavailability that is deficient, or at least reduced in the cases of zinc, calcium and iron.

26 Studies carried out with the Caco-2 cell line supported this hypothesis, showing 
1 inhibition of the iron bioavailability of samples with $40 \%$ flour substitution.

2 Nevertheless, the use of up to $20 \mathrm{~g} / 100 \mathrm{~g}$ amaranth flour allowed an increase in iron

3 uptake with regard to the control sample (Sanz-Penella, Laparra, Sanz \& Haros, 2011).

4 Moreover, it must be emphasized that some lower myo-inositol phosphates are

5 considered compounds that could perform positive biological functions in the human

6 body such as second messenger, bringing about a range of cellular functions including

7 cell proliferation via intracellular $\mathrm{Ca}^{2+}$ mobilization, particularly $\operatorname{Ins} P_{3}$ (Shi, Azab,

8 Thompson \& Greenberg, 2006; Haros et al., 2009).

\section{$10 \quad 3.2$. Technological parameters}

11 The parameters that describe the quality of bread are shown in Table 4. The loaf volume 12 slightly decreased with the addition of amaranth, while the weight of breads remained 13 almost constant among samples. Consequently, the loaf specific volume showed a slight

14 tendency to decrease with the inclusion of amaranth flour up to $40 \mathrm{~g} / 100 \mathrm{~g}$ in the 15 formulation, from 2.74 to $2.51 \mathrm{ml} / \mathrm{g}$, with significant differences for the highest level of 16 addition. The presence of amaranth did not produce meaningful changes in crumb 17 hardness; only the sample with $40 \mathrm{~g} / 100 \mathrm{~g}$ substitution showed a value significantly 18 higher than the control bread. In the case of crumb elasticity, a significant increase was 19 observed in breads with between 30 and $40 \mathrm{~g} / 100 \mathrm{~g}$ with regard to the control sample.

20 Opposite behaviour was shown in cohesiveness, gumminess and VRC parameters, and a 21 significant decrease with regard to the control sample was recorded with the inclusion 22 of amaranth flour. Morita, Kang, Hamazu and Sugimoto (1999) showed a regular 23 increase in hardness of breads with an increase of amaranth flour from 5 to $20 \mathrm{~g} / 100 \mathrm{~g}$.

24 Other researchers observed a significant decrease in loaf specific volume, with harder 25 breads produced when increased levels of replacement with amaranth were used 26 (Bodroza-Solarov et al., 2008). Gluten content is diluted by the inclusion of amaranth 
1 flour, which usually results in slight hardening of the crumb structure. However,

2 Oszvald et al. (2009) found that amaranth albumin proteins are capable of interacting

3 with gluten proteins in wheat flour, showing similar effects to gluten subunits. This

4 could lead to little change in crumb hardness, as the present study shows (Table 4). On

5 the other hand, the lipid content in amaranth flour, which is 6 times higher than in wheat

6 flour, may act as a surface active agent. The high polar lipid content in amaranth, in

7 general about $10 \mathrm{~g} / 100 \mathrm{~g}$ of total lipids, may have functionality as a gas stabilising agent

8 during breadmaking, which probably improves bread elasticity (Alvarez-Jubete et al.,

$92010)$.

10 The effect of the inclusion of amaranth flour on crumb structure showed no significant

11 changes in nearly all of the parameters analysed, although some slight variations were

12 observed. Only a significant increase in the mean cell area was recorded for the samples

13 with a substitution percentage between 20 and $40 \mathrm{~g} / 100 \mathrm{~g}$. Moreover, the samples with

14 amaranth flour showed a tendency to increase cell area, but without significant

15 differences with regard to the control sample. There were changes in crumb and crust

16 colour due to the inclusion of amaranth flour, which were estimated by the CIELab

17 system (Table 4). In general, the tristimulus colour values in both crumb and crust were

18 affected when the amaranth concentration was raised (Table 4). The crust redness was

19 statistically higher in breads with amaranth, whereas the yellowness showed an opposite

20 behaviour in comparison with the control sample. The crust lightness showed slight

21 changes and was significantly lower than the control bread when a high concentration of

22 amaranth flour was used in the formulation. Crumb tristimulus colour parameters were

23 more affected than the crust with the inclusion of amaranth flour. Lightness was

24 significantly lower than the control, with darker, more strongly coloured crumbs, with

25 greater red and yellow components. The typical darker colour of amaranth flour in 
1 comparison with wheat flour affected the colour parameters of the bread, particularly in

2 the crumb section.

3 Preliminary sensory evaluation studies of breads made with whole amaranth flour

4 showed that they did not achieve greater acceptability than the control bread. They were

5 described as having a different flavour, a slightly bitter nutty taste (results not shown).

6 The consumers also concluded that if bread with amaranth (in proportions between 10

7 and $20 \mathrm{~g} / 100 \mathrm{~g}$ ) is more nutritious they would choose to consume it even though its taste

8 and aroma are different from those of traditional bread.

10 4. Conclusions

11 Whole amaranth flour from Amaranthus cruentus could be used as a replacement for 12 wheat flour in bread formulations, increasing the product's nutritional value and 13 providing an increase in dietary fibre (with the resistant starch level remaining constant) 14 and also mineral and protein levels, with a slight depreciation in bread performance 15 when used in proportions between 10 and $20 \mathrm{~g} / 100 \mathrm{~g}$. High levels of phytates were 16 found in amaranth flour and this contributed to similarly high phytate levels in bread 17 containing high proportion of amaranth $(30-40 \mathrm{~g} / 100 \mathrm{~g})$, which could affect the mineral 18 bioavailability of zinc, calcium and iron, as was predicted by phytate/mineral ratios. The 19 inclusion of amaranth flour in bakery products could be limited to a maximum 20 proportion of $20 \mathrm{~g} / 100 \mathrm{~g}$, not only for maintaining product quality but also for 21 preserving the principal nutritional benefit of this ingredient.

\section{Acknowledgements}

24 This work was financially supported by projects AGL2006-09613/ALI, 200870I229 and 252006 PL0015 from the Ministry of Science and Innovation (MICINN), and 
1 PROMETEO/2012/064 from Generalitat Valenciana, Spain. The fellowship of J.M.

2 Sanz Penella from MICINN is gratefully acknowledged. The authors express sincere 3 appreciation to Prof. Jadwiga Sadowska for her assistance in the bread crumb texture 4 analysis and to J.A. Tamayo-Ramos for his aid in the bread performance tests.

\section{References}

7 Alvarez-Jubete, L., Auty, M., Arendt, E. K., \& Gallagher, E. (2010). Baking properties 8 and microstructure of pseudocereal flours in gluten free bread formulations. European $9 \quad$ Food Research and Technology, 230, 437-445.

10 AOAC. (1991). Total, Soluble, and Insoluble Dietary Fiber in Foods. In K. Helrich 11 (Eds.), Official Methods of Analysis (15 ${ }^{\text {th }}$ ed.; $3^{\text {rd }}$ Supplement; Section 991.43). 12 Arlington, VA: Association of Official Analytical Chemists.

13 AOAC. (1996). Starch (Total) in Cereal Products, Amyloglucosidase/ $\alpha$-Amylase 14 Method. Official Methods of Analysis (15 ${ }^{\text {th }}$ ed.; $3^{\text {rd }}$ Supplement; Section 996.11). 15 Arlington, VA: Association of Official Analytical Chemists.

16 Bodroza-Solarov, M., Filiocev, B., Kevresan, Z. Mandic, A., \& Simurina, O. (2008).

17 Quality of bread supplemented with popped Amaranthus cruentus grain. Journal of 18 Food Process Engineering, 31, 602-618.

19 Bohn, L., Meyer, A.S., Rasmussen, S.K. (2008). Phytate: impact on environment and 20 human nutrition. A challenge for molecular breeding. Journal of Zhejiang University21 Science B, 9, 165-191.

22 Budin, J. T., Breene, W. M., \& Putnam, D. H. (1996). Some compositional properties of 23 seeds and oils of eight Amaranthus species. Journal of the American Oil Chemists 24 Society, 73, 475-481. 
1 Champ, M., Martin, L., Noah, L., \& Gratas, M. (1999). Analytical methods for resistant

2 starch. In S. Sungsoo Cho, L. Prosky \& Dreher, M. (Eds.), Complex Carbohydrates in

$3 \quad$ Food (pp. 184-187). New York: Marcel Dekker Inc.

4 Colmenares de Ruiz, A. S., \& Bressani, R. (1990). Effect of germination on the

5 chemical composition and nutrition value of amaranth grain. Cereal Chemistry, 67, $6 \quad 519-522$.

7 Dyner, L., Drago, S. R., Piñeiro, A., Sánchez, H., González, R., Villamil, E., \& 8 Valencia, M.E. (2007). Composition and potential contribution of iron, calcium and 9 zinc of bread and pasta made with wheat and amaranth flours. Archivos 10 Latinoamericanos de Nutrición, 57, 69-78.

11 Gamel, T. H., Linssen, J. P., Mesallam, A. S., Damir, A. A., \& Shekib, L. A. (2006). 12 Seed treatments affect functional and antinutritional properties of amaranth flours. 13 Journal of the Science of Food and Agriculture, 86, 1095-1102.

14 Haros, M., Rosell, C.M. \& Benedito, C. (2001). Use of fungal phytase to improve 15 breadmaking performance of whole wheat bread. Journal of Agricultural and Food 16 Chemistry, 49, 5450-5454.

17 Haros, M., Carlsson, N.G., Almgrem, A., Larsson Alminger, M., Sandberg, A.S., \& 18 Andlid, T. (2009). Phytate degradation by human gut isolated Bifidobacterium 19 pseudocatenulatum ATCC27919 and its probiotic potential. International Journal of 20 Food Microbiology, 135, 7-14.

21 Hurrell, R.F., Reddy, M.B., Juillerat, M.A., \& Cook, J.D. (2003). Degradation of phytic 22 acid in cereal porridges improves iron absorption by human subjects. American Journal of Clinical Nutrition, 77, 1213-1219.

24 Kumar, V., Sinha, A.K., Makkar, H.P.S., \& Becker, K. (2010). Dietary roles of phytate 25 and phytase in human nutrition: A review. Food Chemistry, 120, 945-959. 
1 Lopez, H. W., Krespine, V., Guy, C., Messager, A., Demigne, C., \& Remesy, C. (2001).

2 Prolonged fermentation of whole wheat sourdough reduces phytate level and increases

3 soluble magnesium. Journal of Agricultural and Food Chemistry, 49, 2657-2662.

4 Lorenz, K., \& Wright, B. (1984). Phytate and tannin content of amaranth. Food

5 Chemistry, 14, 27-34.

6 Ma, G., Jin, Y., Plao, J., Kok, F., Guusie, B, \& Jacobsen, E. (2005). Phytate, Calcium,

7 Iron, and Zinc contents and their molar ratios in foods commonly consumed in China.

8 Journal of Agricultural and Food Chemistry, 53, 10285-10290.

9 Marquart, L., Asp, N.G., \& Richardson, D.P. (2004). Whole grain health claims in the

10 United States, United Kingdom and Sweden. In J.W. Van der Kamp, N.G. Asp, J.M.

11 Jones, G. Schaafsma (Eds.), Dietary fibre - Bio-Active Carbohydrates for Food and

12 Feed (pp. 39-57). The Netherlands: Wageningen Academic Publishers.

13 Miller Jones, J. (2009). The Second C\&E Spring Meeting and Third International

14 Whole Grain Global Summit. Cereal Foods World, 54, 132-135.

15 Morita, N., Kang, W. W., Hamazu, Z., \& Sugimoto, Y. (1999). Effect of Amaranth

16 flour on some properties of wheat dough and bread. The Japanese Society of Applied

17 Glycoscience, 26, 23-30.

18 National Academy of Sciences. Institute of Medicine. (2004). Food and Nutrition

19 Board. Dietary Reference Intakes: Recommended Intakes for Individuals, vitamins,

20 minerals and macronutrients.

21 Oszvald, M., Tamás, C., Rakszegi, M., Tömösközi, S., Békés, F., \& Tamás, L. (2009).

22 Effects of incorporated amaranth albumins on the functional properties of wheat dough.

23 Journal of the Science of Food and Agriculture, 89, 882-889.

24 Sadowska, J., Błaszczak, W., Fornal, J., Vidal-Valverde, C., \& Frias, J. (2003). Changes

25 of wheat dough and bread structure and quality as a result of germinated pea flour

26 addition. European Food Research and Technology A, 216, 46-50. 
1 Sandberg, A.S., Hulthen, L.R., \& Türk, M. (1996). Dietary Aspergillus niger phytase

2 increases iron absorption in humans. Human and Clinical Nutrition, 126, 476-480.

3 Sandstrom, B., \& Sandberg, A.S. (1992). Inhibitory effects of isolated inositol

4 phosphates on zinc absorption in humans. Journal of Trace Elements and Electrolytes in

$5 \quad$ Health and Disease, 6, 99-103.

6 Sanz-Penella, J. M., Collar, C., \& Haros, M. (2008). Effect of wheat bran and enzyme

7 addition on dough functional performance and phytic acid levels in bread. Journal of

8 Cereal Science, 48, 715-721.

9 Sanz-Penella, J.M., Tamayo-Ramos, J.A., Sanz, Y., \& Haros, M. (2009). Phytate

10 reduction in bran-enriched bread by phytase-producing Bifidobacteria. Journal of 11 Agricultural and Food Chemistry, 57, 10239-10244.

12 Sanz-Penella, J. M., Tamayo-Ramos, J. A., Wronkowska, M., Soral-Smietana, M., \& 13 Haros, M. (2010). Impact of the addition of resistant starch from modified pea starch on 14 dough and bread performance. European Food Research and Technology, 231, 49915508.

16 Sanz-Penella, J.M., Laparra, J.M., Sanz, Y., \& Haros, M. (2012). Bread supplemented 17 with amaranth (Amaranthus cruentus): Effect of phytates on in vitro iron absorption. 18 Plant Food for Human Nutrition, 67, 50-56.

19 Shi, Y., Azab, A.N., Thompson, M.N., \& Greenberg, M.L. (2006). Inositol phosphates

20 and phosphainositides in health and disease. Subcellular Biochemistry, 39, 265-292.

21 Sindhuja, A., Sudha, M. L., \& Rahim, A. (2005). Effect of incorporation of amaranth 22 flour on the quality of cookies. European Food Research and Technology, 221, 59723601.

24 Skrbic, B., \& Filipcev, B. (2008). Nutritional and sensory evaluation of wheat breads 25 supplemented with oleic-rich sunflower seed. Food Chemistry, 108, 119-129. 
1 Teutonico, R. A., \& Knorr, D. (1985). Amaranth: composition, properties and

2 applications of a rediscovered food crop. Food Technology, 39, 49-61.

3 Tosi, E. A., Re, E. D., Masciarelli, R., Sanchez, H., Osella, C., \& de la Torre, M. A.

4 (2002). Whole and defatted hyperproteic amaranth flours tested as wheat flour

5 supplementation in mold breads. LWT - Food Science and Technology, 35, 472-475.

6 Türk, M., \& Sandberg, A. S. (1992). Phytate degradation during breadmaking - effect

7 of phytase addition. Journal of Cereal Science, 15, 281-294.

8 Whiteside, P., \& Miner, B. (1984). Pye Unicam Atomic Absorption Data Book.

9 Cambridge: Pye Unicam Ltd.

10 Wronkowska, M., Troszynska, A., Soral-Smietana, M., \& Wolejszo, A. (2008). Effects

11 of buckwheat flour (Fagopyrum esculentum moench) on the quality of gluten-free 12 bread. Polish Journal of Food and Nutrition Sciences, 58, 211-216. 
1 Table 1. Mineral and myo-inositol phosphates content of flours

\begin{tabular}{lccc}
\hline Sample $^{\mathrm{a}}$ & Units $^{\mathbf{b}}$ & Wheat flour & Whole amaranth flour \\
\hline Ash & $\mathrm{g} / 100 \mathrm{~g}$ & $0.53 \pm 0.01$ & $2.44 \pm 0.08$ \\
Microelements & & & \\
$\mathrm{Cu}$ & $\mu \mathrm{g} / \mathrm{g}$ & $1.83 \pm 0.03$ & $6.94 \pm 0.01$ \\
$\mathrm{Mn}$ & $\mu \mathrm{g} / \mathrm{g}$ & $5.82 \pm 0.01$ & $36.55 \pm 0.12$ \\
$\mathrm{Zn}$ & $\mu \mathrm{g} / \mathrm{g}$ & $7.35 \pm 0.10$ & $42.08 \pm 0.32$ \\
$\mathrm{Fe}$ & $\mu \mathrm{g} / \mathrm{g}$ & $12.66 \pm 0.04$ & $82.13 \pm 0.17$ \\
$\mathrm{Macroelements}$ & & & \\
$\mathrm{Ca}$ & $\mathrm{mg} / \mathrm{g}$ & $0.22 \pm 0.01$ & $2.04 \pm 0.01$ \\
$\mathrm{Mg}$ & $\mathrm{mg} / \mathrm{g}$ & $0.25 \pm 0.01$ & $2.69 \pm 0.01$ \\
$\mathrm{P}$ & $\mathrm{mg} / \mathrm{g}$ & $1.11 \pm 0.02$ & $5.30 \pm 0.02$ \\
$\mathrm{Na}$ & $\mu \mathrm{g} / \mathrm{g}$ & $112.4 \pm 1.4$ & $8.21 \pm 0.27$ \\
$\mathrm{~K}$ & $\mathrm{mg} / \mathrm{g}$ & $1.56 \pm 0.01$ & $4.70 \pm 0.03$
\end{tabular}

\section{Myo-inositol phosphates}

$\begin{array}{lccc}\text { Ins } P_{6} & \mu \mathrm{mol} / \mathrm{g} & \text { n.d. } & 21.1 \pm 2.1 \\ \mathrm{Ins} P_{5} & \mu \mathrm{mol} / \mathrm{g} & \text { n.d. } & 2.3 \pm 0.5 \\ \mathrm{Ins} P_{4} & \mu \mathrm{mol} / \mathrm{g} & \text { n.d. } & 0.86 \pm 0.08 \\ \mathrm{Ins} P_{3} & \mu \mathrm{mol} / \mathrm{g} & \text { n.d. } & \text { n.d. }\end{array}$

$2{ }^{\mathrm{a}}$ Mean $\pm \mathrm{SD}, \mathrm{n}=3 ; \operatorname{Ins} P_{3}$ to Ins $P_{6}: m y o$-inositol containing 3-6 phosohates per inositol residue; not

3 detected (n.d.). ${ }^{\mathrm{b}}$ Units expressed in dry matter.

4 
1 Table 2. Effect of different amount of whole amaranth flour on chemical composition of 2 bread $^{\mathrm{ab}}$

\begin{tabular}{lccccc}
\hline Sample & Control & 10WAF & 20WAF & 30WAF & 40WAF \\
\hline Main components $(\mathrm{g} / 100 \mathrm{~g}$ d.m. $)$ & & & & \\
Moisture $^{\mathrm{c}}$ & $38.79 \pm 0.03 \mathrm{a}$ & $39.94 \pm 0.08 \mathrm{c}$ & $39.55 \pm 0.03 \mathrm{~b}$ & $41.94 \pm 0.03 \mathrm{e}$ & $40.51 \pm 0.10 \mathrm{~d}$ \\
Starch & $68.21 \pm 0.03 \mathrm{~d}$ & $68.78 \pm 0.19 \mathrm{~d}$ & $66.61 \pm 0.16 \mathrm{c}$ & $65.52 \pm 0.06 \mathrm{~b}$ & $63.78 \pm 0.03 \mathrm{a}$ \\
Proteins & $14.29 \pm 0.05 \mathrm{a}$ & $14.66 \pm 0.17 \mathrm{ab}$ & $14.96 \pm 0.35 \mathrm{~b}$ & $16.14 \pm 0.31 \mathrm{c}$ & $16.30 \pm 0.05 \mathrm{c}$ \\
Lipids & $0.67 \pm 0.03 \mathrm{a}$ & $0.97 \pm 0.05 \mathrm{~b}$ & $1.29 \pm 0.08 \mathrm{c}$ & $1.36 \pm 0.03 \mathrm{~d}$ & $1.75 \pm 0.07 \mathrm{e}$ \\
Ash & $1.35 \pm 0.01 \mathrm{a}$ & $1.54 \pm 0.01 \mathrm{c}$ & $1.50 \pm 0.02 \mathrm{~b}$ & $1.87 \pm 0.04 \mathrm{~d}$ & $2.06 \pm 0.02 \mathrm{e}$ \\
\hline Dietary fibre (g/100g d.m.) & & & & \\
Insoluble & $1.91 \pm 0.13 \mathrm{a}$ & $2.35 \pm 0.02 \mathrm{ab}$ & $2.96 \pm 0.10 \mathrm{bc}$ & $3.44 \pm 0.04 \mathrm{c}$ & $4.17 \pm 0.14 \mathrm{~d}$ \\
Soluble & $1.88 \pm 0.13 \mathrm{a}$ & $1.84 \pm 0.02 \mathrm{a}$ & $1.67 \pm 0.04 \mathrm{a}$ & $1.62 \pm 0.07 \mathrm{a}$ & $1.73 \pm 0.15 \mathrm{a}$ \\
Total & $3.79 \pm 0.23 \mathrm{a}$ & $4.19 \pm 0.01 \mathrm{~b}$ & $4.63 \pm 0.06 \mathrm{c}$ & $5.06 \pm 0.03 \mathrm{~d}$ & $5.90 \pm 0.01 \mathrm{e}$ \\
Resistant starch & $1.81 \pm 0.08 \mathrm{a}$ & $2.04 \pm 0.04 \mathrm{bc}$ & $2.10 \pm 0.10 \mathrm{c}$ & $1.94 \pm 0.11 \mathrm{ab}$ & $1.90 \pm 0.06 \mathrm{ab}$ \\
\hline
\end{tabular}

\section{Mineral content}

Microelements ( $\mu \mathrm{g} / \mathrm{g}$ d.m.)

$\begin{array}{lrrrrr}\mathrm{Cu} & 2.25 \pm 0.01 \mathrm{a} & 2.58 \pm 0.02 \mathrm{~b} & 3.77 \pm 0.02 \mathrm{~d} & 3.98 \pm 0.04 \mathrm{c} & 4.21 \pm 0.01 \mathrm{e} \\ \mathrm{Mn} & 6.39 \pm 0.02 \mathrm{a} & 9.99 \pm .0 .09 \mathrm{~b} & 13.02 \pm 0.04 \mathrm{c} & 16.39 \pm 0.04 \mathrm{~d} & 19.41 \pm 0.11 \mathrm{e} \\ \mathrm{Zn} & 11.65 \pm 0.25 \mathrm{a} & 15.75 \pm 0.04 \mathrm{~b} & 18.55 \pm 0.20 \mathrm{c} & 21.67 \pm 0.15 \mathrm{~d} & 24.91 \pm 0.04 \mathrm{e} \\ \mathrm{Fe} & 18.85 \pm 0.11 \mathrm{a} & 22.66 \pm 0.13 \mathrm{~b} & 30.05 \pm 0.27 \mathrm{c} & 35.91 \pm 0.43 \mathrm{~d} & 43.74 \pm 0.28 \mathrm{e}\end{array}$

Macroelements (mg/g d.m.)

$\begin{array}{llllll}\mathrm{Ca} & 0.31 \pm 0.01 \mathrm{a} & 0.48 \pm 0.01 \mathrm{~b} & 0.64 \pm 0.01 \mathrm{c} & 0.85 \pm 0.02 \mathrm{~d} & 0.99 \pm 0.04 \mathrm{e} \\ \mathrm{Mg} & 0.29 \pm 0.01 \mathrm{a} & 0.53 \pm 0.01 \mathrm{~b} & 0.75 \pm 0.01 \mathrm{c} & 1.04 \pm 0.01 \mathrm{~d} & 1.32 \pm 0.02 \mathrm{e} \\ \mathrm{P} & 1.27 \pm 0.01 \mathrm{a} & 1.81 \pm 0.01 \mathrm{~b} & 2.12 \pm 0.02 \mathrm{c} & 2.60 \pm 0.01 \mathrm{~d} & 3.05 \pm 0.03 \mathrm{e} \\ \mathrm{K} & 1.88 \pm 0.02 \mathrm{a} & 2.22 \pm 0.05 \mathrm{~b} & 2.42 \pm 0.01 \mathrm{c} & 2.86 \pm 0.01 \mathrm{~d} & 3.21 \pm 0.02 \mathrm{e}\end{array}$

Myo-inositol phosphates ( $\mu \mathrm{mol} / \mathrm{g}$ d.m.)

$\begin{array}{lccccc}\text { Ins } P_{6} & \text { n.d. } & \text { n.d. } & 0.11 \pm 0.01 \mathrm{a} & 0.91 \pm 0.01 \mathrm{~b} & 2.35 \pm 0.02 \mathrm{c} \\ \mathrm{Ins} P_{5} & \text { n.d. } & \text { n.d. } & 0.24 \pm 0.06 \mathrm{a} & 0.65 \pm 0.03 \mathrm{~b} & 0.83 \pm 0.04 \mathrm{c} \\ \mathrm{Ins} P_{4} & \text { n.d. } & 0.65 \pm 0.02 \mathrm{a} & 2.06 \pm 0.14 \mathrm{~b} & 2.65 \pm 0.02 \mathrm{c} & 2.51 \pm 0.01 \mathrm{c} \\ \mathrm{Ins} P_{3} & 0.31 \pm 0.08 \mathrm{a} & 2.29 \pm 0.08 \mathrm{~b} & 2.35 \pm 0.14 \mathrm{~b} & 2.88 \pm 0.10 \mathrm{c} & 3.07 \pm 0.06 \mathrm{c}\end{array}$

3 a Codes: Control, 10WAF, 20WAF, 30WAF and 40WAF: amount of amaranth flour 0, 10, 20, 30 and $40 \mathrm{~g} / 100 \mathrm{~g}$

4 of flour, respectively. Dry matter (d.m.); $\operatorname{Ins} P_{3}$ to $\operatorname{Ins} P_{6}$ : myo-inositol containing 3-6 phosohates per inositol

5 residue; not detected (n.d.). ${ }^{b} \mathrm{Mean} \pm \mathrm{SD}, \mathrm{n}=3$. Values followed by the same letter in the same row are not

6 significantly different $(p<0.05) .{ }^{c}$ Wet basis. 
1 Table 3. Contribution of micro- and macroelement intake to the relevant dietary reference 2 intakes (DRIs) for consumption of a daily average portion of $250 \mathrm{~g}$ of bread incorporating 3 whole amaranth flour

\begin{tabular}{|c|c|c|c|c|c|c|c|}
\hline \multirow[t]{2}{*}{ Nutrient } & \multirow[t]{2}{*}{ Gender } & \multirow{2}{*}{$\begin{array}{c}\text { DRIs }^{\mathbf{a}} \\
\text { mg/day }\end{array}$} & \multicolumn{5}{|c|}{ Contribution to DRIs $(\%)^{b, c}$} \\
\hline & & & Control & 10WAF & 20WAF & 30WAF & 40WAF \\
\hline \multicolumn{8}{|c|}{ Microelements } \\
\hline $\mathrm{Cu}$ & Adults & 0.9 & 38.3 & 43.0 & 60.8 & 66.8 & 69.6 \\
\hline \multirow[t]{2}{*}{$\mathrm{Mn}$} & Male & 2.3 & 42.5 & 65.2 & 85.5 & 103.4 & 125.5 \\
\hline & Female & 1.8 & 54.3 & 83.3 & 109.3 & 132.2 & 160.4 \\
\hline \multirow[t]{2}{*}{$\mathrm{Zn}$} & Male & 11 & 16.2 & 21.5 & 25.5 & 28.6 & 33.7 \\
\hline & Female & 8 & 22.3 & 29.6 & 35.0 & 39.3 & 46.3 \\
\hline \multirow[t]{2}{*}{$\mathrm{Fe}$} & Male & 8 & 36.1 & 42.5 & 57.8 & 65.2 & 81.3 \\
\hline & Female & $18 *$ & 16.0 & 18.9 & 25.2 & 29.0 & 36.1 \\
\hline
\end{tabular}

\section{Macroelements}

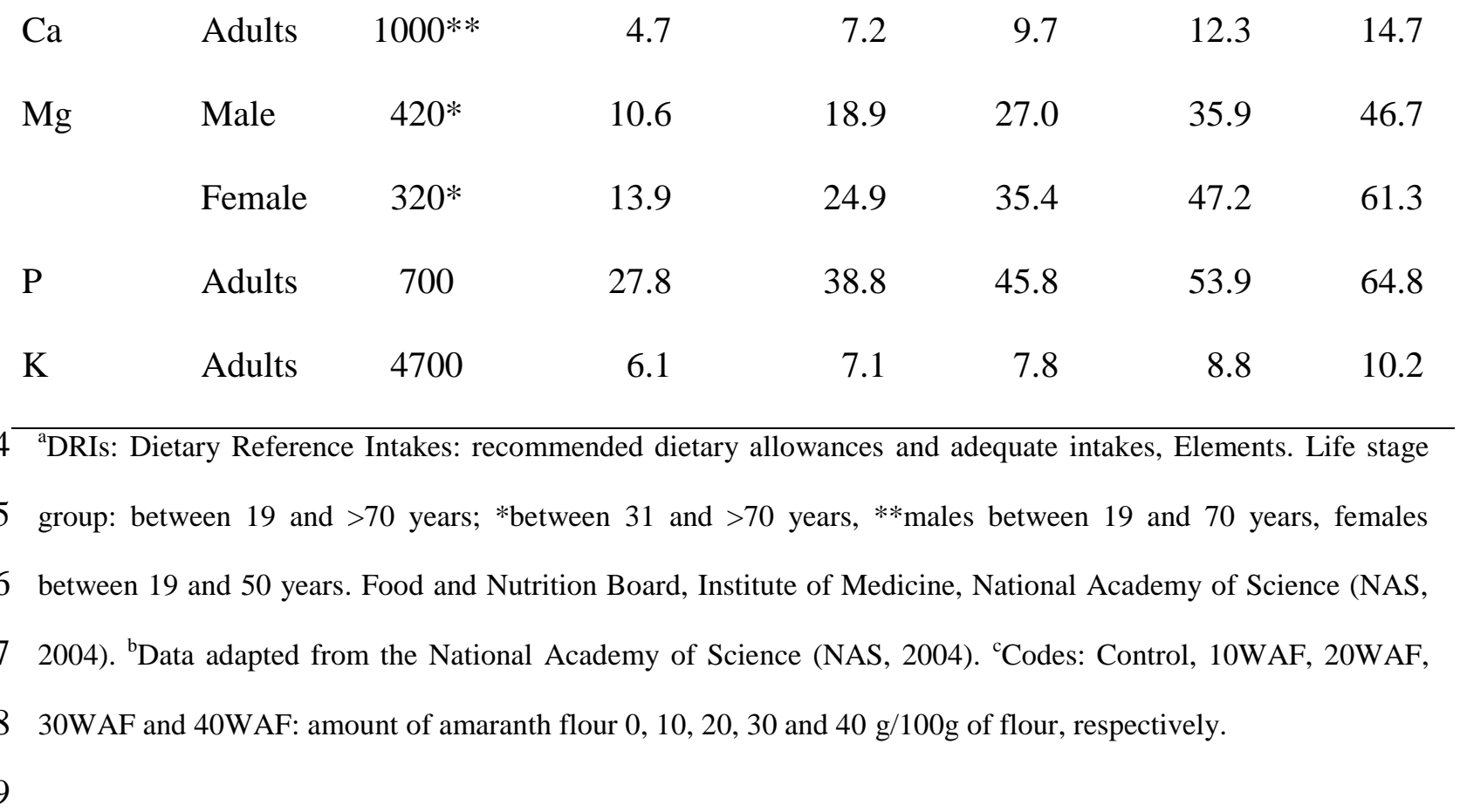


1 Table 4. Effect of different amount of whole amaranth flour on bread quality

\begin{tabular}{|c|c|c|c|c|c|}
\hline Sample $^{\mathbf{a}}$ & Control & 10WAF & 20WAF & 30WAF & 40WAF \\
\hline \multicolumn{6}{|c|}{ Technological parameters $^{b}$} \\
\hline Loaf volume $\left(\mathrm{cm}^{3}\right)$ & $620 \pm 26 b$ & $619 \pm 23 b$ & $606 \pm 26 b$ & $598 \pm 30 b$ & $553 \pm 21 a$ \\
\hline Loaf weight (g) & $226 \pm 5 b$ & $225.7 \pm 2.8 b$ & $225.0 \pm 3.9 \mathrm{~b}$ & $226.5 \pm 2.3 b$ & $220.4 \pm 3.5 \mathrm{a}$ \\
\hline Specific volume $\left(\mathrm{cm}^{3} / \mathrm{g}\right)$ & $2.74 \pm 0.16 b$ & $2.74 \pm 0.11 b$ & $2.70 \pm 0.15 b$ & $2.64 \pm 0.14 \mathrm{ab}$ & $2.51 \pm 0.10 \mathrm{a}$ \\
\hline \multicolumn{6}{|l|}{ Textural parameters $^{\mathrm{c}}$} \\
\hline Hardness (KPa) & $24.9 \pm 4.0 \mathrm{a}$ & $25.1 \pm 5.2 \mathrm{a}$ & $26.9 \pm 4.8 \mathrm{a}$ & $29.5 \pm 5.2 \mathrm{ab}$ & $31.9 \pm 3.0 \mathrm{~b}$ \\
\hline Elasticity & $0.83 \pm 0.03 a$ & $0.83 \pm 0.03 a$ & $0.85 \pm 0.02 \mathrm{a}$ & $0.90 \pm 0.02 c$ & $0.90 \pm 0.02 b$ \\
\hline Cohesiveness & $0.45 \pm 0.03 d$ & $0.44 \pm 0.05 \mathrm{~d}$ & $0.36 \pm 0.02 c$ & $0.31 \pm 0.02 b$ & $0.30 \pm 0.01 \mathrm{a}$ \\
\hline Gumminess (KPa) & $11.0 \pm 1.2 \mathrm{c}$ & $10.9 \pm 1.2 b$ & $9.8 \pm 1.8 \mathrm{ab}$ & $9.2 \pm 1.4 \mathrm{ab}$ & $9.4 \pm 0.8 \mathrm{a}$ \\
\hline VRC & $0.70 \pm 0.07 \mathrm{~d}$ & $0.69 \pm 0.07 \mathrm{c}$ & $0.59 \pm 0.04 \mathrm{~b}$ & $0.47 \pm 0.02 \mathrm{a}$ & $0.48 \pm 0.02 \mathrm{a}$ \\
\hline \multicolumn{6}{|c|}{ Crust Colour parameters $^{d}$} \\
\hline $\mathrm{L}^{*}$ & $47.0 \pm 2.2 \mathrm{a}$ & $48.7 \pm 2.8 \mathrm{a}$ & $48.6 \pm 2.8 \mathrm{a}$ & $47.6 \pm 4.3 \mathrm{a}$ & $42.7 \pm 3.3 b$ \\
\hline$a^{*}$ & $13.2 \pm 1.9 \mathrm{a}$ & $13.8 \pm 1.2 \mathrm{ab}$ & $14.9 \pm 0.7 \mathrm{c}$ & $14.1 \pm 0.7 \mathrm{bc}$ & $14.3 \pm 0.6 \mathrm{c}$ \\
\hline$b^{*}$ & $31.1 \pm 1.9 \mathrm{a}$ & $30.5 \pm 1.6 \mathrm{ab}$ & $28.2 \pm 2.4 \mathrm{c}$ & $30.5 \pm 3.3 \mathrm{ab}$ & $28.6 \pm 1.6 b c$ \\
\hline \multicolumn{6}{|c|}{ Crumb Colour parameters ${ }^{d}$} \\
\hline $\mathrm{L}^{*}$ & $58.9 \pm 1.6 \mathrm{a}$ & $56.5 \pm 1.6 \mathrm{~b}$ & $54.8 \pm 1.3 \mathrm{c}$ & $53.0 \pm 1.6 \mathrm{~d}$ & $54.2 \pm 2.5 \mathrm{~cd}$ \\
\hline$a^{*}$ & $1.89 \pm 0.16 \mathrm{a}$ & $2.70 \pm 0.15 b$ & $3.30 \pm 0.14 c$ & $4.88 \pm 0.16 \mathrm{~d}$ & $5.84 \pm 0.37 \mathrm{e}$ \\
\hline$b^{*}$ & $21.4 \pm 0.4 \mathrm{a}$ & $22.0 \pm 0.5 \mathrm{ab}$ & $22.3 \pm 0.5 b$ & $25.5 \pm 0.4 \mathrm{c}$ & $27.4 \pm 0.8 \mathrm{~d}$ \\
\hline \multicolumn{6}{|c|}{$\begin{array}{l}2 \text { 'ades: Control, 10WAF, 20WAF, 30WAF and 40WAF: amount of amaranth flour 0, 10, 20, } 30 \text { and } 40 \mathrm{~g} / 100 \mathrm{~g} \\
3 \text { of flour, respectively. Volume Recovery Coefficient or Springiness (VRC). Mean } \pm \text { SD, }{ }^{b} \mathrm{n}=6 ;{ }^{\mathrm{c}} \mathrm{n}=8 ;{ }^{\mathrm{d}} \mathrm{n}=15 . \\
4 \text { Values followed by the same letter in the same row are not significantly different }(p<0.05 \text { ). }\end{array}$} \\
\hline
\end{tabular}

